\title{
The Urban Heat Budget Derived from Satellite Data
}

\section{Eberhard Parlow, Basel}

\section{The urban heat island}

In Central Europe up to $85 \%$ of the population lives in cities or urban agglomerations (UNITED NATIONS 2000). This makes the urban climate and its anthropogenic modifications an important issue for planners, scientists and policy makers. The urban climate differs completely from that of rural or forested areas. Since urban surfaces are extremely heterogeneous the interaction with the urban boundary layer is very complex and there are only a few micro-meteorological measurements existing providing us with sufficient data of the urban radiation and energy balance. For many years, remotely sensed data have been used in urban climate studies. Most of these data are in the thermal infrared band between 8 and $14 \mu \mathrm{m}$ where the spatially distributed surface temperature can be measured. In many publications this is often used as an indicator for the urban heat island (UHI). Long-wave emission, calculated from surface temperature data, is however only one variable among others important for the characterisation of net radiation and heat balance. The UHI is a characteristic feature of the urban climate. Used alone, it can thus lead to inconsistent results. In general, mean air temperatures in cities are several degrees higher than in rural environments or in forested areas. This is true not only of big cities, but also of provincial towns. A more detailed analysis shows that in most cases the UHI-effects can be detected in annual, monthly and daily means and in mobile measurements made at night. Detailed investigations during daytime are very seldomly carried out (ALEXANDER 1988). Satellite or aerial thermal imagery always show surface temperatures of urban areas which are 10 to $15 \mathrm{~K}$ higher than the surrounding rural areas. This is one reason why high surface temperatures are often used as an indicator of high air temperatures - but this is not necessarily the case for urban surfaces.

Fig. 1 shows an example of the city of Basel (Switzerland) with an inner city station (Spalenring) compared to a rural site (Fischingen). The figure shows air temperature differences between urban and rural conditions for the year 1994. Positive temperature differences indicate a warmer city compared to rural conditions. With the exception of a few days the city is always warmer than the rural site. Integrated over daily or monthly time intervals the UHI effect can clearly be demonstrated. An interesting feature develops if shorter time intervals of measurements are compared, e.g. hourly or 10-min averages. Fig. 2 shows an isopleth diagram of air temperature differences between the same stations and the same year as presented in Fig. 1. The UHI effect is clearly visible during night-time over the whole year between 18 and 6 hours and during winter during the whole day. But between April and October there is a clear modification of the thermal situation: the urban air temperature is mostly up to $2 \mathrm{~K}$ colder than at the rural site. This indicates that an urban cooling island (UCI) is often well developed during daytime, despite the high surface temperatures. This feature can be seen for other years and by using other meteorological stations available in the Basel area (FEHRENBACH 1999).

\section{The energy balance}

The left side of the energy balance equation (Eq. 1) shows the fluxes of short-wave and long-wave radiation $\left(E_{G}, E_{R}, E_{A}, E_{T}\right)$ which sum up to the net radiation $Q_{o}$. The right side of the equations stands for the turbulent and diffusive heat fluxes which balance the net radiation. The energy balance equation can be formulated as follows:

$\left(E_{G}-E_{R}+E_{A}-E_{T}\right)=\left(Q_{G}+Q_{E}+Q_{H}\right)$

with:

$E_{G}=$ solar irradiance

$E_{R}=$ short wave reflection

$E_{A}=$ atmospheric counter radiation

$E_{T}=$ terrestrial emission

$Q_{G}=$ storage flux

$Q_{E}=$ latent heat flux

$Q_{H}=$ sensible heat flux

Net radiation is controlling the turbulent fluxes and the storage heat flux into the ground and the building structures, respectively. Normally, net radiation is positive during daytime which enables heat fluxes into the atmosphere. During night-time, net radiation is mostly negative resulting in a decrease of air temperature or condensation. Thus net radiation determines the direction of heat fluxes (from ground to atmosphere or vice versa). In most urban climate studies based on satellite data only the terrestrial emission $\left(E_{T}\right)$ is derined from surface temperature measurements. As can be seen in the equation above, terrestrial emission is only one of four variables necessary for the analysis of net radiation. Surface temperature is directly coupled with 


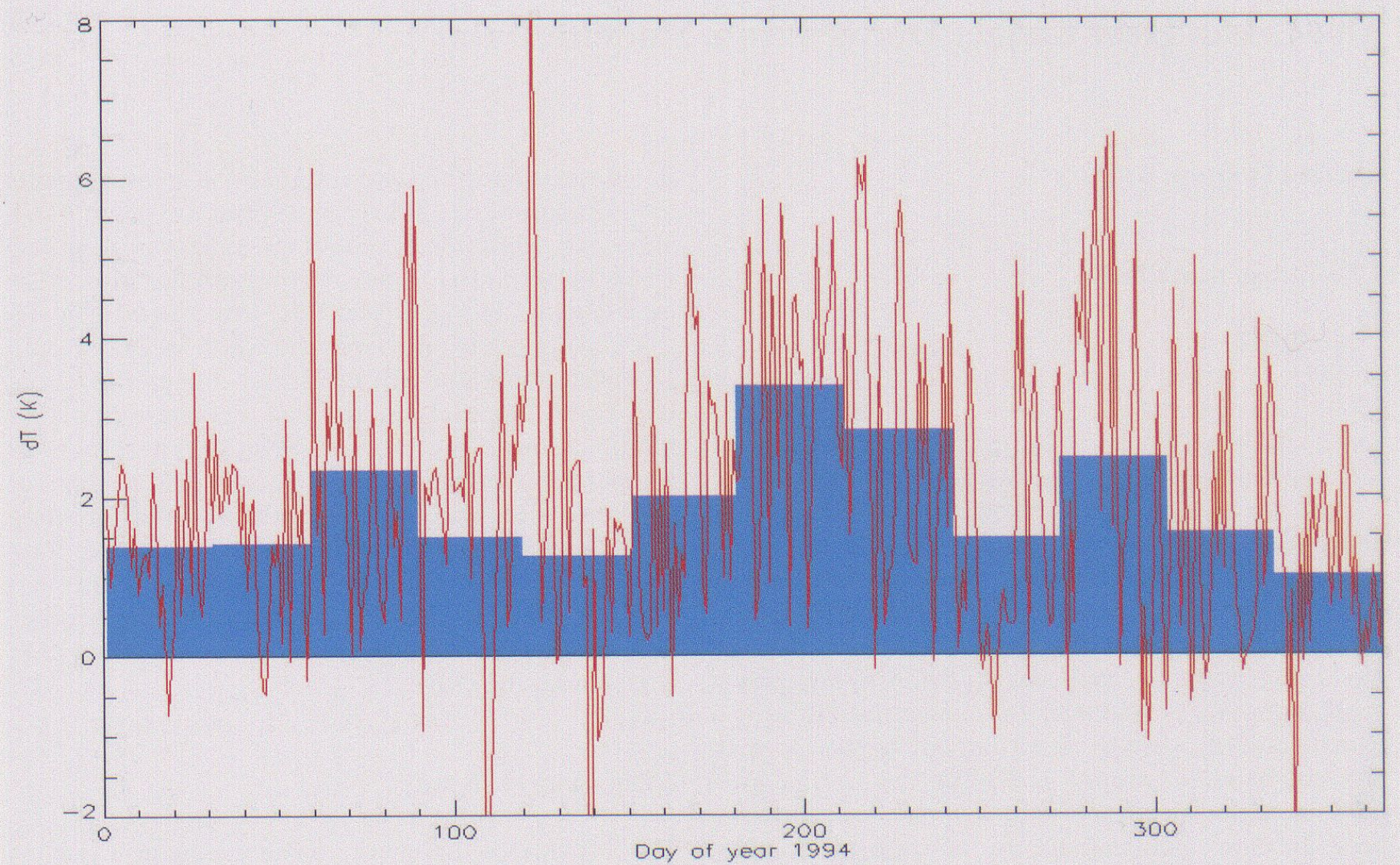

Figure 1: Temperature difference between an urban and a rural station at Basel, Switzerland for 1994. The bars indicate monthly means, the lines daily means.

Temperaturdifferenz und Tagesmitteltemperaturen zwischen einer urbanen und einer ruralen Messstation in Basel/ Schweiz für das Jahr 1994. Balken: Monatsmitteltemperaturen, Linien: Tagesmitteltemperaturen

Différences de température et températures moyennes quotidiennes entre une station de mesures urbaine et une station de mesures rurale à Bâle/Suisse, en 1994. Barre: températures moyennes mensuelles; lignes: températures moyennes quotidiennes

terrestrial emission through the law of Stefan-Boltzmann:

$$
E_{T}=\sigma \varepsilon T^{4}
$$

Due to high surface temperatures there is an increased longwave radiative loss from urban surfaces which is not compensated by an increase in short-wave radiation. It is easy to understand that misinterpretation of thermal infrared satellite images is likely if only one variable of net radiation is considered.

Fig. 3 (left) shows the spatial distribution of surface temperatures and net radiation of the city of Basel, Switzerland, at the time of a Landsat-TM satellite overpass on July $7^{\text {th }}, 1984$. The high surface temperatures of urban surfaces (surrounded by a black line) reach up to $30^{\circ} \mathrm{C}$. Temperatures between 15 and $20^{\circ} \mathrm{C}$ are characteristic of rural and forested sites. The River Rhine, crossing the city centre, has the lowest surface temperature. The spa- tial distribution of net radiation at the time of the satellite overpass (Fig. 3 right) shows that the city is characterised by a moderate net radiation and that we find the lowest values of net radiation at the warmest parts of the city or at Basel airport to the northwest. The highest net radiation corresponds to cooler surfaces (forests, River Rhine) or to sun-exposed locations in the nearby mountains where we have a surplus of solar irradiance due to slope and aspect conditions. Therefore, it is an erroneous assumption that high surface temperatures of urban surfaces are closely correlated with high air temperatures. The latter are the result of a complex interaction of the spatially distributed net radiation, the available energy for sensible heat flux and the local wind field which drives the vertical fluxes. Concerning methodological aspects of the computation of net radiation, refer to PARLOW (1996a).

A visual comparison with surface temperature clearly indicates that the spatial pattern of net radiation dif- 

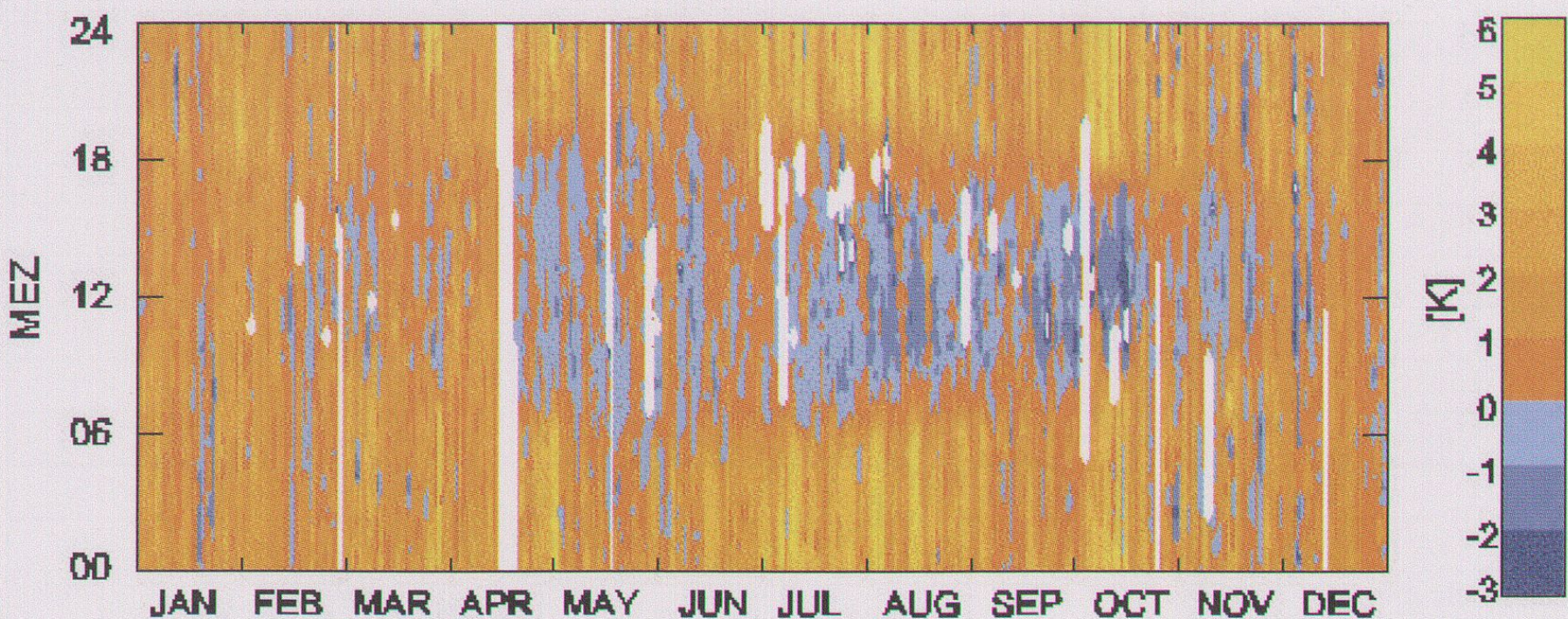

Figure 2: Isopleths of temperature difference between an urban and a rural station at Basel/Switzerland for 1994. The X-axis shows the Day of Year (DOY) and den Y-axis the day time between 0 and 24 hours measured every 10 minutes. Orange and yellow colours indicate a warmer city and blue colours a cooler city. The white colour is used for missing data at one of the two stations.

Thermoisoplethen der Temperaturdifferenz zwischen einer urbanen und einer ruralen Station in Basel/Schweiz für das Jahr 1994. $x$-Achse: Tage des Jahres, y-Achse: Tageszeit zwischen 0 und 24 Uhr, Messung in 10-Minutenmittelwerten. Orange und gelb deuten auf eine warme Stadt, blaue Farbtöne weisen auf eine kühlere Stadt hin. Weisse Stellen bedeuten Datenlücken an einer der beiden Stationen.

Thermoisopleths de la différence de température entre une station urbaine et une station rurale à Bâle/Suisse, en 1994. Axe x: journées dans l'année; axe y: temps entre 0 et 24 heures; mesures effectuées en séquences moyennes d'intervalles de 10 minutes. Orange et jaune: une ville chaude; teintes en bleu: une ville plus fraîche; en blanc, des lacunes de données dans l'une des deux stations.
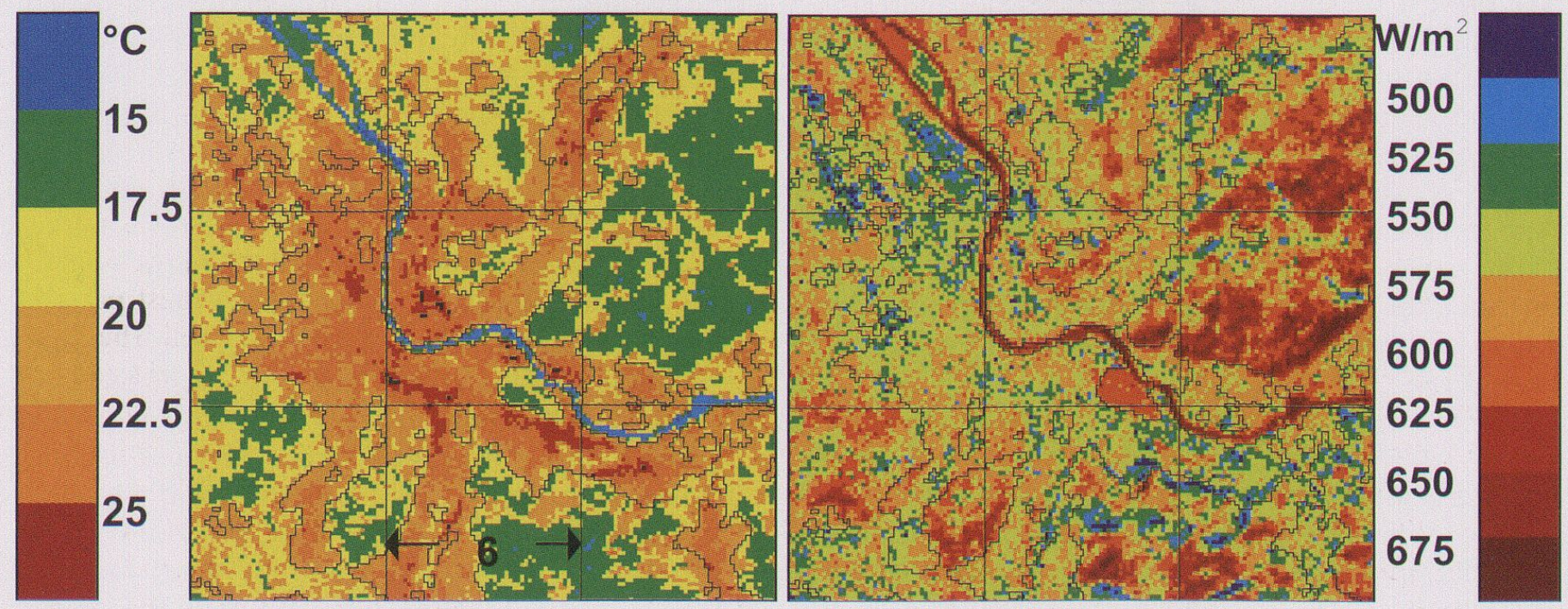

Figure 3: Surface temperature (left) and net radiation (right) of Basel, computed from Landsat-TM data (July 7, 1984

Oberflächentemperatur (links) und Strahlungsbilanz (rechts) von Basel, berechnet aus Landsat-TM-Satellitendaten vom 7. Juli 1984

Température de surface (à gauche), bilan radiatif (à droite), à Bâle. Base de calcul: données satellitales Landsat TM, 7.7.1984 


\begin{tabular}{|l|c|c|c|c|}
\hline Term of energy balance & $\begin{array}{c}\text { Source/ } \\
\text { computation }\end{array}$ & Rural & $\begin{array}{c}\text { Urban 1 } \\
\text { e.g. city center }\end{array}$ & $\begin{array}{c}\text { Urban 2 } \\
\text { e.g. industry }\end{array}$ \\
\hline$E_{G}\left(\mathrm{~W} / \mathrm{m}^{2}\right)$ & measurement & 800 & 800 & 800 \\
\hline Albedo a & satellite data & 0.15 & 0.19 & 0.2 \\
\hline$E_{R}\left(\mathrm{~W} / \mathrm{m}^{2}\right)$ & $\mathrm{a} \cdot E_{G}$ & 120 & 152 & 160 \\
\hline$E_{A}\left(\mathrm{~W} / \mathrm{m}^{2}\right)$ & measurement & 320 & 320 & 320 \\
\hline Surface temp. $T_{o}\left({ }^{\circ} \mathrm{C}\right)$ & satellite data & 22 & 28 & 30 \\
\hline$E_{T}\left(\mathrm{~W} / \mathrm{m}^{2}\right)$ & $\sigma \bullet T_{o}$ & 430 & 467 & 479 \\
\hline$Q_{o}\left(\mathrm{~W} / \mathrm{m}^{2}\right)$ & $E_{G}-E_{R}+E_{A}-E_{T}$ & 569 & 500 & 480 \\
\hline$Q_{G} / Q_{o}$ & measurement & 0.1 & 0.4 & 0.5 \\
\hline$Q_{G}\left(\mathrm{~W} / \mathrm{m}^{2}\right)$ & & 57 & 200 & 240 \\
\hline Available energy $\left(\mathrm{W} / \mathrm{m}^{2}\right)$ & $Q_{o}-Q_{G}$ & 512 & 300 & 240 \\
\hline$Q_{E} /\left(Q_{o}-Q_{G}\right)$ & assumption & 0.5 & 0.2 & 0.1 \\
\hline$Q_{E}\left(\mathrm{~W} / \mathrm{m}^{2}\right)$ & & 256 & 60 & 24 \\
\hline$Q_{H}\left(\mathbf{W} / \mathbf{m}^{2}\right)$ & $Q_{o}-Q_{G}-Q_{E}$ & $\mathbf{2 5 6}$ & $\mathbf{2 4 0}$ & $\mathbf{2 1 6}$ \\
\hline
\end{tabular}

Tab. 1: Difference of energy balance between rural and urban surfaces

Differenz der Energiebilanz zwischen ländlichen und städtischen Oberflächen

Différence du bilan d'énergie entre les surfaces en milieu urbain et celles en milieu rural

fers completely from surface temperature. A statistical correlation between the images results in $\mathrm{R}=-0.39$. The most striking feature is that in contrast to the distribution of surface temperature urban areas are not clearly outlined in the net radiation data (Fig. 3, right). For industrial sites, net radiation values around 500 $\mathrm{W} / \mathrm{m}^{2}$ can be found, urban and agricultural areas have similar conditions with values around $600 \mathrm{~W} / \mathrm{m}^{2}$, the cool forests and water surfaces show maximum values in the range of 625 to nearly $700 \mathrm{~W} / \mathrm{m}^{2}$. It is thus obvious that the interpretation of thermal infrared data has to be done against the background of the energy balance.

\section{General aspects of urban heat fluxes}

Material properties of surfaces such as thermal conductivity, heat capacity and thermal admittance can be identified as the reason for the high surface temperature of urban areas. These differ greatly from rural conditions. The storage heat flux $Q_{G}$ can be expressed as a ratio of the net radiation $Q_{o}$. Under a clear sky in day time and for natural surfaces like forests, meadows etc. the ratio $Q_{G} / Q_{o}$ is mostly between 0.05 and 0.15 , but strongly increases for urban surfaces to more than 0.30 . For the city of Basel, the ratio, which is based on continuous measurements, lies between 0.30 and 0.40 (Christen et al. 2002). Grimmond et al. (1996) published values of up to 0.60 for North-American cities. The ration in tropical cities, like Mexico city, is not much different. JÁUREGUI et al. (1996) and OKE (1992) prove this with measurements between 0.47 and 0.52 . That means that urban surfaces, such as houses, roads etc., store 30 to $50 \%$ of net radiation. It is easy to compute how much energy is left for the turbulent processes $Q_{E}$ and $Q_{H}$. Even in cities a minimum evaporation is guaranteed through trees in streets, parks, lawns etc. Some basic computations are documented in Table 1. Data are compiled from satellite data analysis, measurements and literature. One rural and two different urban surfaces are presented. According to Fig. 3, net radiation decreases with increasing surface temperature. The ratios $Q_{G} / Q_{o}$ in Tab. 1 are taken from literature. It is obvious that storage heat flux $Q_{G}$ is extremely high in the case of an urban surface and therefore available energy $\left(Q_{o}\right.$ $-Q_{G}$ ) is lowest compared to rural conditions. Assuming a minimal evapotranspiration which is expressed by the ratio $Q_{E} /\left(Q_{o}-Q_{G}\right)$, the sensible heat flux $Q_{H}$ is lower than under rural conditions. In the case of highest surface temperatures, evapotranspiration can be totally neglected and yet available energy for $Q_{H}$ will be even lower. 

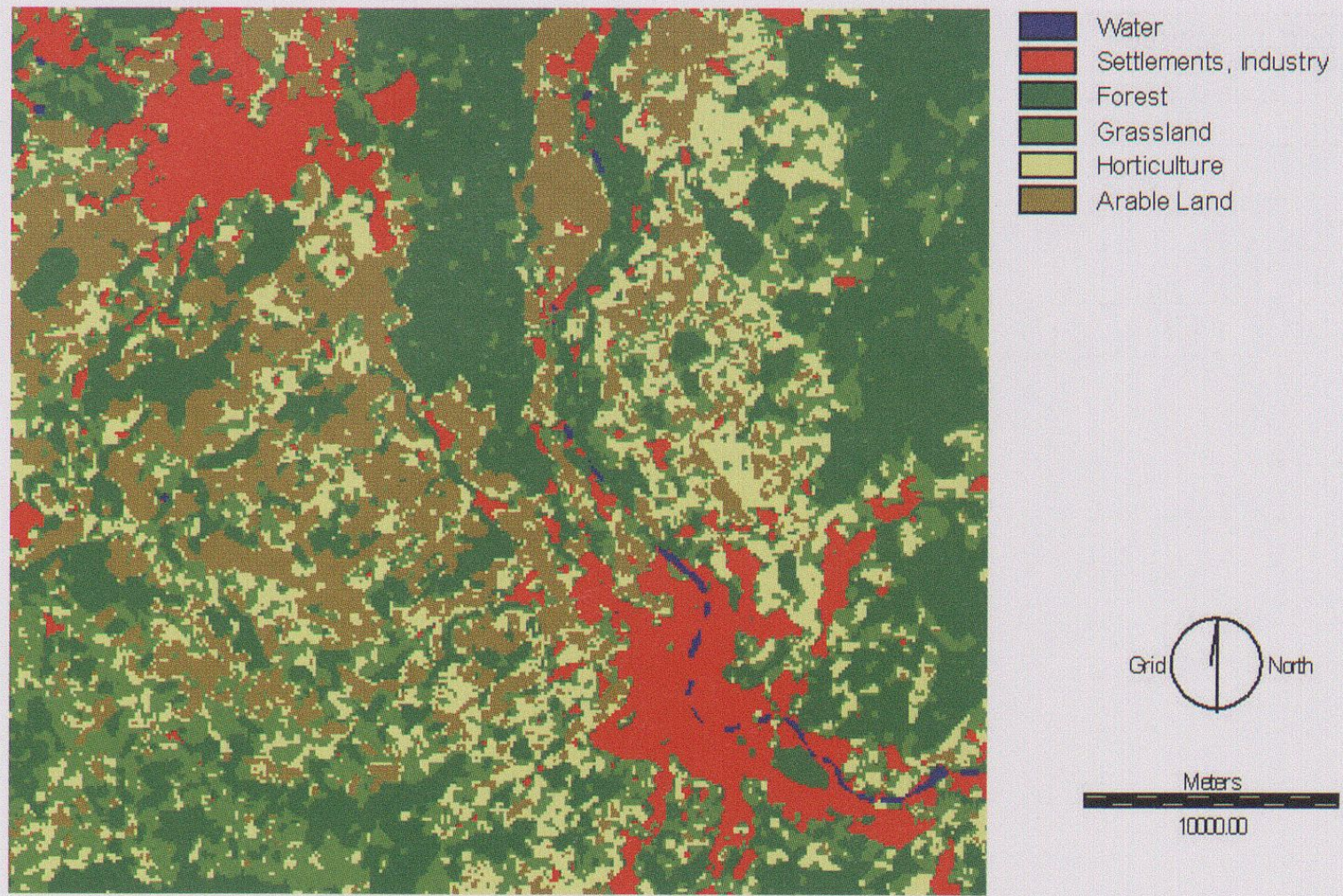

Figure 4: Land use classification of Basel region (reduced to six classes), computed from Landsat-TM data (May 3, 1995)

Landnutzungsklassifikation der Region Basel (reduziert auf 6 Klassen), berechnet aus Landsat-TM-Satellitendaten vom 3. Mai 1995

Classement de l'occupation du sol en région bâloise (réduit à six classes), effectué à partir de la base de données Landsat TM du 3.5.1995

\section{The satellite computations of heat fluxes}

Satellite data have specific spatial and temporal resolutions which is often a drawback for urban climate studies. If the temporal resolution enables time series analysis with several satellite overpasses per day (NOAA-AVHRR), then the spatial resolution normally does not meet the requirements of urban climate studies. On the other hand, when LandsatTM data with a spatial resolution of $30 \mathrm{~m}$ in the solar and $60 \mathrm{~m}$ respectively $120 \mathrm{~m}$ in the thermal channel are used, giving a rather good differentiation of the urban structures, then the drawback is that data are available only on a 16 days repeat cycle and during the warm-up phase in the morning (around 1000 hours local time). Nevertheless, these data can be used for case studies on how the different urban structures (different residential areas, city center, industrial sites etc.) behave as far as net radiation and heat fluxes are concerned. If a detailed land use classification exists in a digital form (Fig. 4) it is possible to analyse these properties in a statistical way.
As far as radiation and heat fluxes are concerned, satellite data can be used to compute the spatially distributed albedo by using the information of the solar wavelengths. After correction of the atmospheric influence on Landsat-TM channel 6 measurements, thermal band data can be used directly to calculate terrestrial emission. To compute the downward radiation fluxes a digital terrain model can be used to calculate the solar irradiance and the atmospheric counter radiation for each grid point by using numerical radiation models. The sum of all these radiation fluxes gives the spatially distributed net radiation $Q_{0}$ for the time of the satellite overpass on May 3, 1995 (Fig. 5), which is influenced by land use and topography effects. Net radiation of forested areas is up to $100 \mathrm{~W} \mathrm{~m}^{-2}$ higher than for urban or industrial areas. For further information refer to PARLOW (2000).

The next steps in the data processing are the computation of the storage heat flux and the available energy $\left(Q_{0}-Q_{G}\right)$. Finally, to estimate the turbulent fluxes $\left(Q_{E}\right.$ and $\left.Q_{H}\right)$, a Bowen ratio approach is used. Many authors have tried to estimate the storage heat flux 


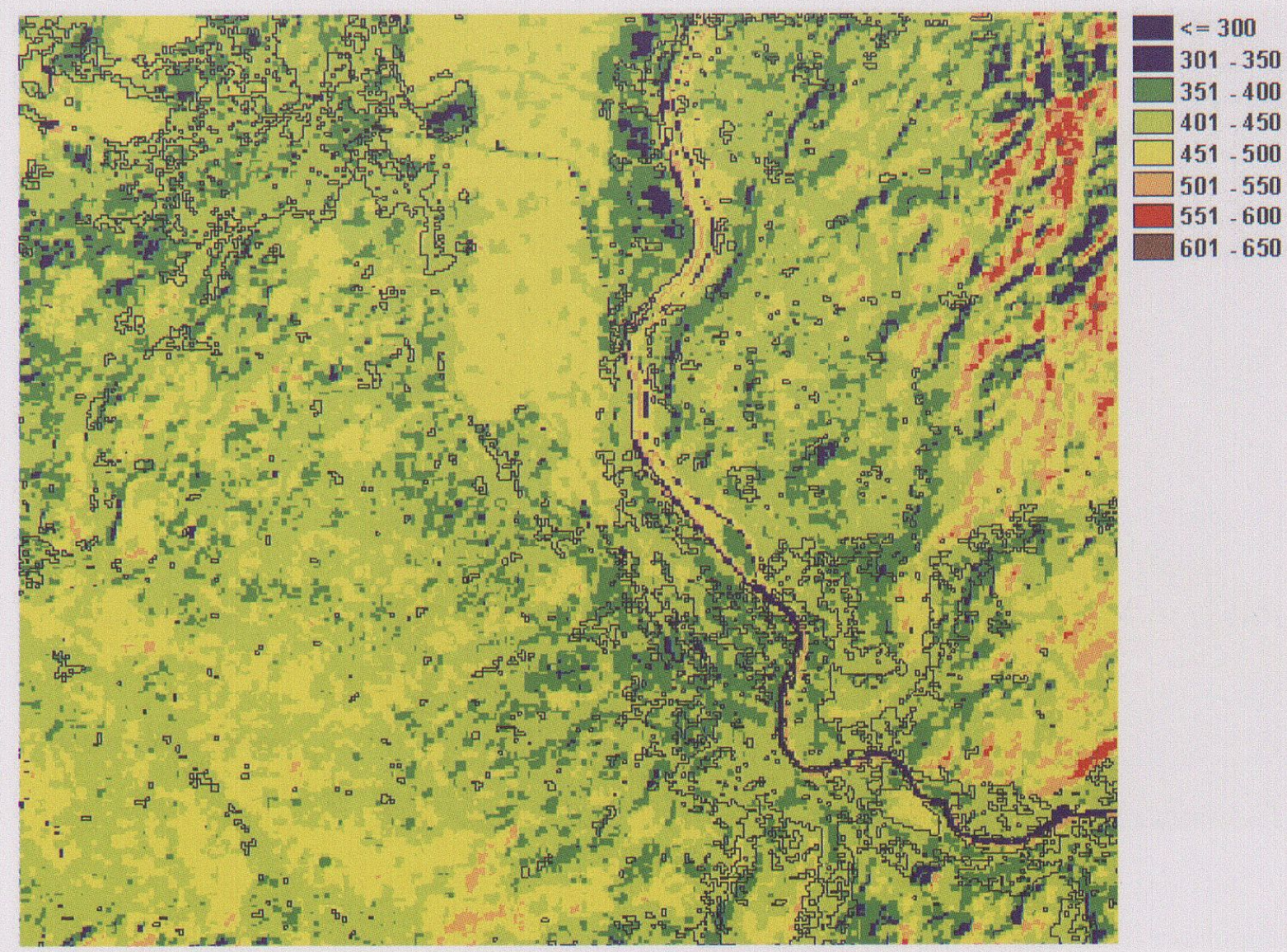

Figure 5: Net radiation of Basel region during Landsat-TM overpass (May 3,1995)

Strahlungsbilanz der Region Basel während des Landsat-TM-Überfluges vom 3. Mai 1995

Bilan radiatif de la région de Bâle durant le survol Landsat TM du 3 mai 1995

$Q_{G}$ from the analysis of the Normalized Difference Vegetation Index (NDVI) and net radiation. NDVI data can be easily computed from satellite data of visible red and infrared wavelengths according to the formula:

$$
N D V I=\left(D N_{\text {red }}-D N_{\text {infrared }}\right) /\left(D N_{\text {red }}+D N_{\text {infrared }}\right)
$$

With: $\quad D N_{\text {red }}$ : digital number in red wavelength $D N_{\text {infrared }}^{\text {red }}$ : digital number in infrared wavelength

The basic idea of this approach is that the density of vegetation acts as a resistance for the storage flux. To a certain extent the vegetation density is correlated with NDVI values from satellite data. KUSTAS \& DAUGHTRY (1990) use the following linear formula:

$$
Q_{G}=(0.325-0.208 \cdot N D V I) \bullet Q_{0}
$$

BASTIAANSSEN et al. (1997) estimate storage flux density by a polynomial function

$$
Q_{G}=0.3 \bullet\left(1-0.98 \cdot N D V I^{4}\right) \bullet Q_{0}
$$

Both approaches give good results on agricultural fields or forested sites. Under these conditions storage heat flux is only a minor part of the heat balance and potential errors do not influence results of turbulent fluxes very much. This differs completely in urban areas where storage heat flux can reach up to $60 \%$ of net radiation.

In this study the storage heat flux $Q_{G}$ of forests $\left(Q_{G(\text { forest })}\right)$, rural $\left(Q_{G(\text { (rural) }}\right)$ and urban areas $\left(Q_{G(\text { urban })}\right)$ is calculated separately. $Q_{\text {G(rural) }}$ is strongly influenced by topographic conditions and solar irradiance. During a satellite overpass at about 0945 hours western slopes can show upward (positive) storage heat fluxes whereas eastern and sunexposed slopes can have downward (negative) storage fluxes at the same time. To tackle this problem, the shortwave net radiation $Q_{S W}$ is computed by using a digital terrain model. Therefore, storage flux $Q_{G}$ is calculated by the following equations (MUSA 1998): 

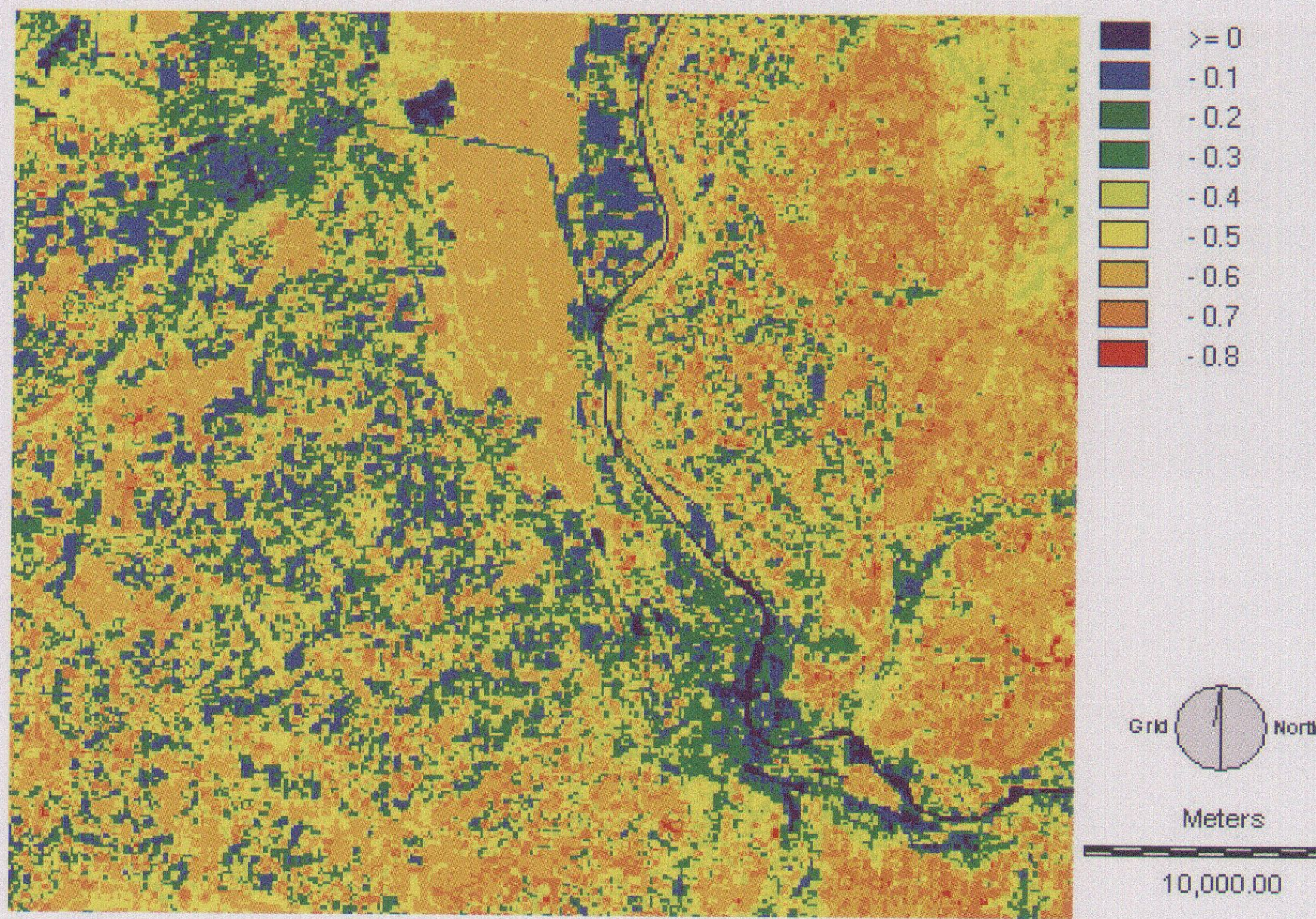

Meters

$10,000.00$

Figure 6: NDVI of Basel computed from Landsat-TM data (bands 3 and 4) (May 3, 1995)

NDVI der Region von Basel berechnet aus Landsat-TM-Daten (Kanäle 3 und 4) am 3. Mai 1995

NDVI de la région de Bâle calculé à partir de données Landsat TM (canaux 3 et 4), le 3 mai 1995

$\mathrm{Q}_{\mathrm{G} \text { (rural) }}=(0.3673-0.3914 \cdot \mathrm{NDVI}) \bullet \mathrm{Q}_{\mathrm{SW}} \bullet(-0.8826 \bullet$ $\left.\ln \left(Q_{\mathrm{SW}}\right)+5.0967\right)$

$\mathrm{Q}_{\mathrm{G}(\text { urban })}=-(0.3673-0.3914 \cdot \mathrm{NDVI}) \cdot \mathrm{Q}_{0} \quad($ eq. 7$)$

$\mathrm{Q}_{\mathrm{G} \text { (forest) }}=-0.5 \bullet(0.3673-0.3914 \cdot \mathrm{NDVI}) \bullet \mathrm{Q}_{0}($ eq. 8$)$

Fig. 6 shows the spatial distribution of NDVI as derived from Landsat-TM data for May 3, 1995. Lowest NDVI values of less than 0.2 can be detected in the city centers of Basel and Mulhouse, as well as on some agricultural fields without vegetation during this time of the year. Highest NDVI, i.e. up to 0.7 and more, is computed for the forests and some grassland areas.

\section{Results}

According to the above mentioned equations, storage heat flux $Q_{G}$ was computed for the whole investigation area. The result is shown in Fig. 7 (left). The urban areas of Mulhouse and Basel and the industrial sites reach maximum values of more than $200 \mathrm{~W} \mathrm{~m}^{-2}$. The forest in the center contrasts strongly with the industrial site with values for $Q_{G}$ in the range of $26-50 \mathrm{~W} \mathrm{~m}^{-2}$. Fig. 7 (right) shows the ratio of $Q_{G} / Q_{0}$. Values in urban areas of Basel and Mulhouse reach 35 to $40 \%$ which agree well with measurements conducted at two sites in the city of Basel. At forested areas the storage heat flux is mostly in the range of $10 \pm 3 \%$ of net radiation.

By averaging all pixels of the different land use classes, mean ratios of $Q_{G} / Q_{0}$ can be derived. The results are presented in Fig. 8. For vegetation covered areas this ratio is between 7 and $10 \%$, but with increasing sealing of the built-up areas values reach up to 25 and 32 $\%$. Ratios of $Q_{G} / Q_{o}$ measured synchronously at the REKLIP energy balance network are shown in Fig. 9. During daytime, ratios are within the range of 5 to $15 \%$ which is in very good agreement with the spatial modelling results. 

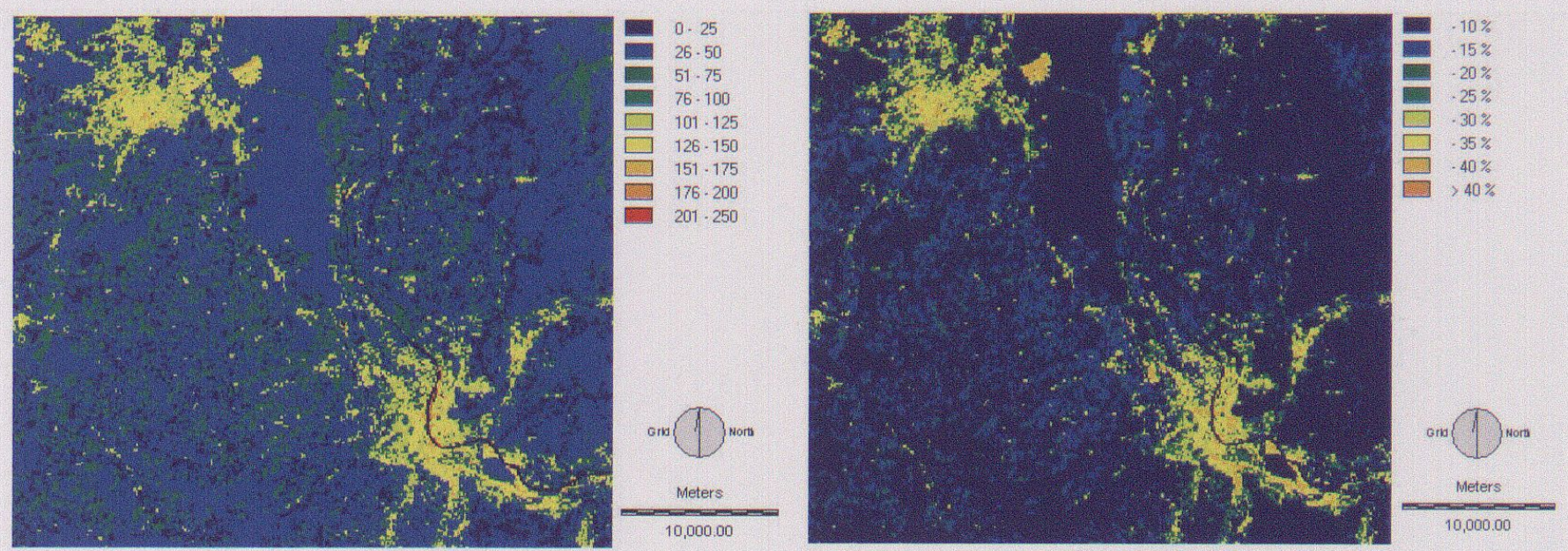

Figure 7: Storage heat flux at satellite overpass on May 3, 1995 (left) in $\mathrm{W} \mathrm{m}^{-2}$ and ratio $G_{0} / Q_{0}$ (right)

Speicherwärmefluss während des Satellitenüberfluges am 3. Mai 1995 (links) in $\mathrm{W} \mathrm{m}^{-2}$ sowie das Verhältnis Speicherwärmefluss zu Strahlungsbilanz $G_{0} / Q_{0}$ (rechts)

Flux de chaleur accumulé durant le survol-satellite du 3 mai 1995 (à gauche) en $W \mathrm{~m}^{-2}$, ainsi que le rapport flux de chaleur accumulé / Bilan radiatif $G_{0} / Q_{0}$ (à droite)

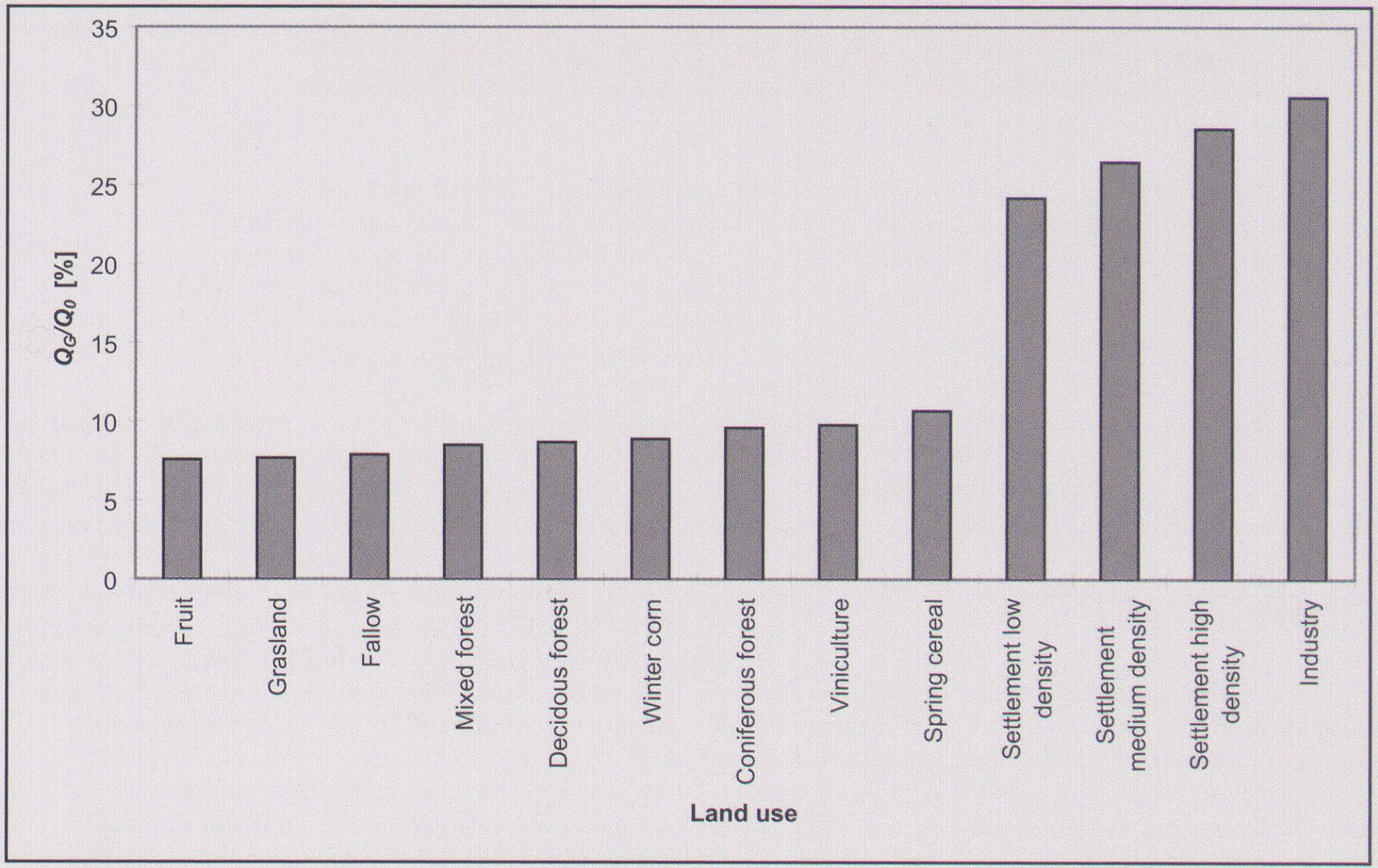

Figure 8: Mean ratios of storage heat flux $\left(Q_{G}\right)$ and net radiation $\left(Q_{0}\right)$ for different land use classes Mittleres Verhältnis des Speicherwärmeflusses $\left(Q_{G}\right)$ und der Strahlungsbilanz $\left(Q_{0}\right)$ für verschiedene Landnutzungsklassen

Rapport moyen de l'accumulation du flux de chaleur $\left(Q_{G}\right)$ au bilan radiatif $\left(Q_{0}\right)$ pour diverses classes d'occupation du sol 


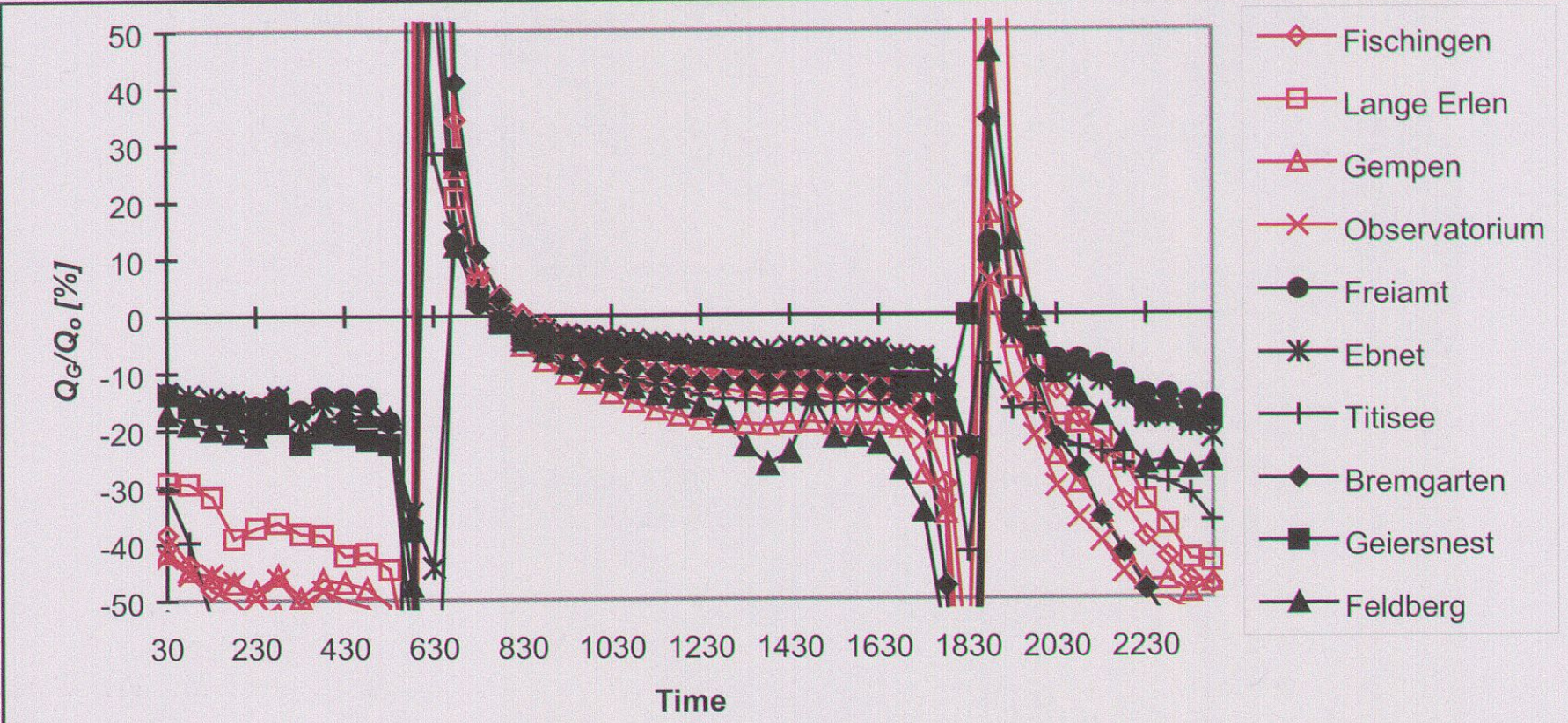

Figure 9: Diurnal course of ratios $Q_{G} / Q_{0}$ at selected stations of the REKLIP energy balance network. During sunrise and sunset, the ratio is not defined due to $Q_{0}=0$.

Tagesgang des Verhältnisses von $Q_{G} / Q_{0}$ an ausgewählten Messstationen des REKLIP-Energiebilanzmessnetzes. Während Sonnenaufgang und -untergang kann das Verhältnis nicht benannt werden $\left(Q_{0}=0\right)$.

Evolution quotidienne du rapport $Q_{G} / Q_{0}$ présentée à partir d'un choix de stations de mesure du réseau de mesure $d u$ bilan d'énergie REKLIP. Durant le lever et le coucher du soleil le rapport ne peut pas être défini $\left(Q_{0}=0\right)$.

In a last step of data analysis Bowen ratios $\left(Q_{H} / Q_{E}\right)$, taken from synchronous measurements of the REKLIP energy balance network (Parlow 1996b), were attributed according to Tab. 2 to the different land use classes. These Bowen ratios are consistent with values published by Hupfer \& Kuttler (1998) or OKe (1987). The Bowen ratio approach enables the computation of the latent $\left(Q_{E}\right)$ and sensible heat fluxes $\left(Q_{H}\right)$ for the whole study area. Fig. 10 (top) shows the results of the computation of latent heat fluxes and Fig. 10 (bottom) shows the same for sensible heat fluxes in $\mathrm{W} \mathrm{m}^{-2}$. Lowest latent heat flux densities of less than $150 \mathrm{~W} \mathrm{~m}^{-2}$ were computed for the urban areas of Basel, Switzerland and Mulhouse, France. Latent heat fluxes of

\begin{tabular}{|l|c|l|c|}
\hline Land use class & Bowen ratio & Land use class & Bowen ratio \\
\hline High density urban & 1.5 & Deciduous forest & 0.4 \\
\hline Medium density urban & 1.0 & Fallow & 0.5 \\
\hline Low density urban & 0.8 & Horticulture \& vineyards & 0.5 \\
\hline Industrial & 1.8 & Grassland & 0.6 \\
\hline Coniferous forest & 0.7 & Arable land & 0.7 \\
\hline Mixed forest & 0.5 & & \\
\hline
\end{tabular}

Tab. 2: Bowen ratios attributed to land use classes Den Landnutzungsklassen zugeordnete Bowen-Verhältnisse Les ratios Bowen attribués aux classes d'occupation du sol 

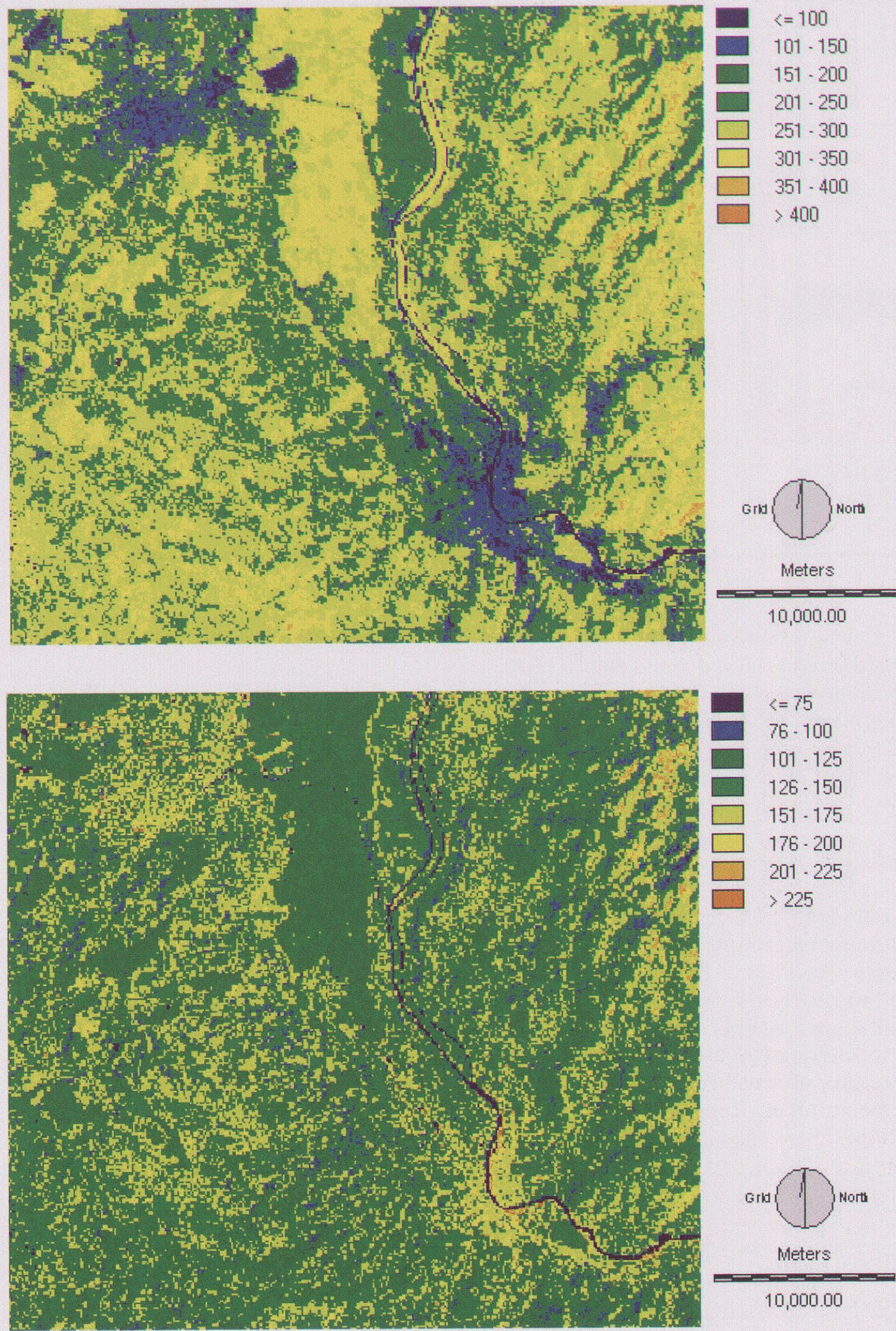

Figure 10: Latent heat flux at satellite overpass (top) and sensible heat flux (bottom). Data in $\mathrm{W} \mathrm{m}^{-2}$.

Latenter Wärmefluss während des Satellitenüberfluges (oben) und fühlbarer Wärmefluss (unten). Daten in $\mathrm{W} \mathrm{m}^{-2}$. Flux de chaleur latente durant le survol-satellite (en haut) et flux de chaleur sensible (en bas); les données sont indiquées en $\mathrm{W} \mathrm{m}^{-2}$. 


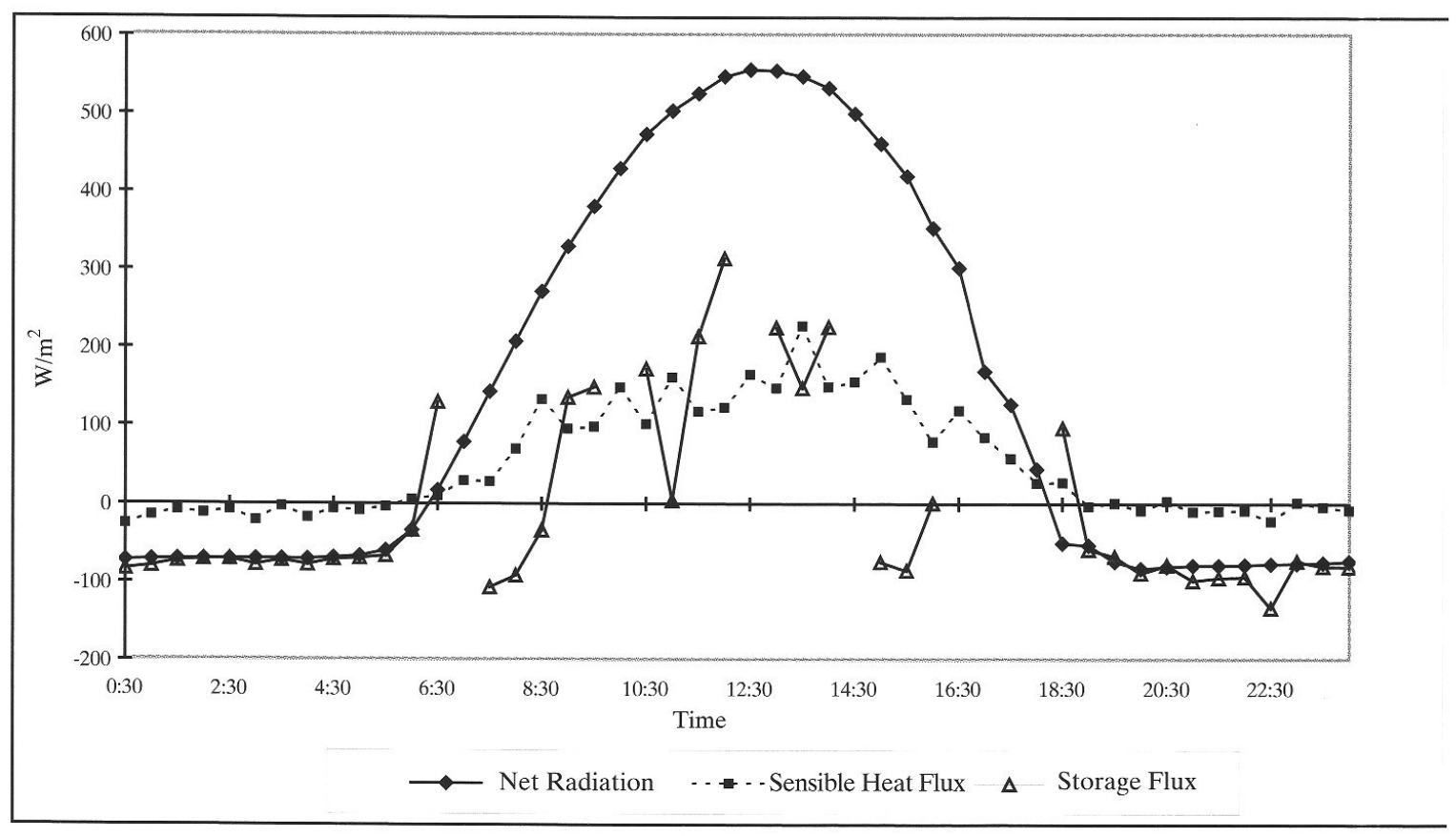

Figure 11: Measurements of net radiation, sensible heat flux and storage heat flux at a micro-meteorological tower in the city center of Basel (Spalenring) for May 3,1995

Messungen von Strahlungsbilanz, fühlbarem Wärmefluss und Speicherwärmefluss an einem Messturm in der Basler Innenstadt (Spalenring) am 3. Mai 1995

Mesures du bilan radiatif, flux de chaleur sensible et flux de chaleur du sol accumulée dans une tour de mesures en centre-ville bâlois(Spalenring), le 3 mai 1995

agricultural sites range between 150 and $250 \mathrm{~W} \mathrm{~m}^{-2}$. The highest evapotranspiration rates are given for the forested sites with latent heat fluxes of up to $350 \mathrm{~W} \mathrm{~m}^{-2}$.

The pattern of the spatially distributed sensible heat flux (Fig. 10 bottom) shows a relatively homogeneous distribution ranging from $100-200 \mathrm{~W} \mathrm{~m}^{-2}$. In this data set, cities and industrial areas are not emphasised. To validate the results of sensible heat flux computations, measurements taken from a micrometeorological tower located in the city center of Basel and equipped with appropriate instruments such as sonic anemometers, were analysed. The results are presented in Fig. 11. Net radiation follows a nearly ideal curve under clear sky conditions. During daytime and at satellite overpass the sensible heat flux ranges between 100 and $200 \mathrm{~W} \mathrm{~m}^{-2}$, which corresponds nicely with spatial computations. Storage heat flux is in the same order of magnitude and even exceeding sensible heat fluxes at certain times. This shows that storage heat flux is a major player in the urban energy balance.

\section{Conclusions}

It could, not surprisingly, be clearly demonstrated that urban and industrial areas can be characterised by low latent heat fluxes. However, sensible heat fluxes in these areas are only slightly higher than or of the same order of magnitude as forested or agricultural sites. This result can be explained by the lower net radiation of urban areas due to high surface temperatures and slightly increased albedo, as well as an extremely high storage flux during daytime. The latter occurs when heat is accumulated in the building material and therefore is not available for the turbulent fluxes. This accumulated energy is finally released during the night to compensate for the negative net radiation of urban areas. Thus, the urban heat island effect is a nighttime feature with temperatures being several degrees higher than at rural sites.

\section{References}

AleXANDeR, J. (1988): Das Zusammenwirken radiometrischer, anemometrischer und topologischer Faktoren im Geländeklima des Weinbaugebietes an der Mittelmosel. $-=$ Forschungen zur Deutschen Landeskunde 230, 185 pp.

BASTIAANSSEN, W.G.M. et al. (1997): A Remote Sensing Surface Energy Balance Algorithm for Land (SEBAL). Part 1: Formulation. - SC-DLO Book, Wageningen NL. Christen A., Vogt, R., Rotach, M.W. \& E. Parlow (2002): First Results from BUBBLE II: Partitioning of 
turbulent heat fluxes over urban surfaces. - AMS $4^{\text {th }}$ Symposium on the Urban Environment, Norfolk VA.: 137-138.

FeHRENBACH, U. (1999): Analyse und Bewertung lokalund regionalklimatisch wirksamer Faktoren in der Region Basel. - Stratus 6, Basel, 177 pp.

Grimmond, S., Oke, T., Spronken-Smith, R.A., Jáuregui, E., Souch, C., Newton, T., King, T.S., Demanes, M., Voogt, J.A. \& M.D. Hubble (1996): Local scale heat storage in North American cities. - International Conference on Urban Climatology, Abstractbook, Essen, $71 \mathrm{pp}$.

Hupfer, P. \& W. KutTler 1998. Witterung und Klima. Stuttgart: Teubner: 413 pp.

Jáuregui, E., Spronken-Smith, R.A., Oke, T. \& A. TejedA-Martinez (1996): Recent energy balance observations in Mexico City. - International Conference on Urban Climatology, Abstractbook, Essen: 77-78.

Kustas, W.P. \& Daughtry, C.S.T. (1990): Estimation of the Soil Heat Flux/Net Radiation Ratio from Spectral Data. - Agricultural and Forest Meteorology 49: 205-223.

MusA, M. (1998): Modellierung des Bodenwärmestromes über urbanen und ruralen Flächen im REKLIP-Untersuchungsgebiet mit Hilfe von Landsat-TMDaten. - Diploma thesis, MCR Lab, University Basel, $104 \mathrm{pp}$.

OKE,T.R. (1987): The surface energy budgets of urban areas. In:American Meteorological Society (ed.): Modeling the urban boundary layer, Boston:1-52.

Oke, T.R., Jauregui, E. \& G. Zeuner (1992): The Surface Energy Balance in Mexico City. - Atmospheric Environment 26B, 4: 433-444.

PArlow, E. (1996a): Net Radiation in the REKLIPArea - A Spatial Approach Using satellite data. - In: PArlow, E. (ed.): Progress in Environmental Remote Sensing Research and Applications, Rotterdam: 429-435.

Parlow, E. (1996b): The Regional Climate Project REKLIP - an overview. - Theoretical and Applied Climatology 53:3-7.

Parlow, E. (2000): Remotely sensed heat fluxes of urban areas. - In: de Dear, R.J., Kalma, J.D., OKe, T.R. \& A. Auliciems (eds): Biometeorology and urban climatology at the turn of the millennium - Selected papers from the conference ICB-ICUC' 99 , WMO/TD No. 1026: 523-528.

UNiTED NATIONS (2000): Indicators on human settlements. - http://www.un.org/Depts/unsd/social/hum-set.htm

\section{Summary: The Urban Heat Budget Derived from Satellite Data}

The study of the interactions between urban surfaces and the urban boundary layer plays an important role in urban climatology, especially seen against the background of increasing urbanisation in most parts of the world. Measurements of radiation and heat fluxes suffer from the extreme heterogeneity of the urban landscape. It is therefore difficult to get accurate and representative measurements. To bridge the gap between accurate point measurements and their spatial representation, satellite data from Landsat-TM are used.

Methods and results of the investigation of radiation properties, net radiation and heat fluxes of urban areas in the Basel Region, NW-Switzerland are presented. In addition to field measurements, satellite data from Landsat-TM were linked to numerical models to compute net radiation and heat fluxes of the whole region. By integrating the normalized difference vegetation index (NDVI) from multi-spectral satellite data, storage heat fluxes could be estimated with high accuracy. The next step was to compute latent and sensible heat fluxes by using a Bowen-ratio approach attributed to a land use classification.

Of interest is the observation that the idea of an «Urban Heat Island» (UHI) has to be defined very carefully. Very often an «Urban Cooling Island» may be found during daytime and under clear sky conditions. This feature could be explained using the results of the satellite based radiation and heat budget analysis.

\section{Zusammenfassung: Der städtische Wärmehaushalt - abgeleitet aus Satellitendaten}

Die Wechselbeziehungen zwischen städtischen Oberflächen und der städtischen Grenzschicht spielen besonders vor dem Hintergrund einer zunehmenden Urbanisierung in den meisten Teilen der Welt eine wichtige Rolle in der Stadtklimatologie. Messungen von Strahlungs- und Wärmeflüssen sind wegen der extremen Heterogenität städtischer Oberflächen aufwendig und daher sehr selten. Um die Lücke zwischen exakten punktuellen Messungen und ihrer räumlichen Verteilung zu überbrücken, werden in diesem Beitrag Satellitendaten von Landsat-TM genutzt.

Es werden Methoden und Ergebnisse von Analysen des Strahlungshaushaltes und der Wärmeflüsse städtischer Oberflächen aus der Region Basel/NW-Schweiz beschrieben. In Ergänzung zu Feldmessungen werden die Landsat-Daten im Zusammenhang mit numerischen Modellen benutzt, um die Strahlungs- und Energiebilanz der gesamten Region zu modellieren. Durch die Einbeziehung des Normalized Difference Vegetation Index (NDVI) kann der Bodenwärmestrom mit hoher Genauigkeit abgeschätzt werden. Die Berechnung des sensiblen und latenten Wärmeflusses erfolgt über einen Bowen-Ratio-Ansatz. Durch ein Attributierungsverfahren werden die Bowen-Ratio-Werte einer vorhandenen Landnutzungsklassifikation zugewiesen. 
Ein interessantes Ergebnis ist es, dass der klassischen Vorstellung der städtischen Wärmeinsel (Urban Heat Island UHI) mit Vorsicht begegnet werden muss. Oftmals entwickelt sich während der Sommertage unter Schönwetterbedingungen und trotz der sehr hohen Oberflächentemperaturen städtischer Oberflächen eine Urban Cooling Island (UCI) mit geringeren Lufttemperaturen als im benachbarten ruralen Umland aus. Dieser Effekt kann auf der Basis der aus Satellitendaten abgeleiteten Energiebilanz erklärt werden.

\section{Résumé: L'observation des flux de chaleur à partir de données satellites}

La corrélation entre les superficies urbaines et la limite de la couche atmosphérique urbaine joue un rôle primordial dans la climatologie urbaine actuelle avec, à l'arrière-plan du scénario, l'urbanisation galopante de la majeure partie du monde. Les mesures de rayonnement et du flux de chaleur turbulente calorifique sont complexes compte tenu de l'extrême hétérogénéité de la superficie urbaine, et de ce fait rares. Pour combler l'abîme entre les mesures ponctuelles exactes et la répartition dans l'espace, ce travail est réalisé avec des données satellites Landsat-TM.

Sont décrits des méthodes et résultats d'analyses de flux de rayonnement et chaleur turbulente des surfaces urbaines de la région de Bâle/région Nord-Ouest de la Suisse. En complément aux mesures de terrain, les données de Landsat sont combinées à des modèles numériques, afin de calculer les bilans radiatifs ainsi que d'énergie de la région tout entière. Pour l'intégration du Normalized Difference Vegetation Index (NDVI), il est possible d'évaluer avec une haute précision le flux de chaleur du sol. Le calcul du flux de chaleur sensible et latente se fait à l'aide d'une mise en équation Bowen-ratio. De ce fait, les données Bowenratio sont attribuées à une classification d'usage du sol existante.
Il est intéressant d'observer que l'idée classique des îlots de chaleur (UHI) urbains se doit d'être prise en considération avec précaution. Souvent se développe pendant les journées estivales et dans des conditions de beau temps, un Urban Cooling Island (UCI) avec des températures inférieures à celles des environs ruraux. Cet effet peut être expliqué par un bilan énergétique fondé sur des données satellites.

\section{Teaching of Geography - pertinent questions}

- What is the influence of temporal integration steps on the analysis of the urban heat island?

- How can the daily urban temperature regime be explained in relation to rural conditions?

- What is the spatial distribution of heat fluxes (sensible, latent and storage flux) compared to urban land use patterns?

- What does UHI stand for and what were the unusual results in the annual measurements?

- Which factors contribute towards the total energy balance and how do they influence or cause lower urban temperatures?

- How does an urban cooling island develop?

Prof. Dr. Eberhard Parlow, Institute of Meteorology, Climatology and Remote Sensing, Department of Geography, University of Basel, Klingelbergstrasse 27, CH-4056 Basel

\author{
Manuskripteingang/received/manuscrit entré le \\ 14.2.2003 \\ Annahme zum Druck/accepted for publication/accepté \\ pour l'impression: 5.6.2003
}

